\title{
Stakeholder Relations Perspectives in Managing Nigeria's Rising Crimes
}

DOI: https://doi.org/10.47175/rissj.v3i1.366

\section{| Daniel Nwanmereni |}

\author{
Department of Mass \\ Communication, Wellspring \\ University, Benin City, Nigeria \\ daniel_nwanmereni@yahoo.com
}

\begin{abstract}
In today's Nigerian society, crime represents a critical stakeholder. The unprecedented rise in crimes, such as, armed robbery, cultism, kidnapping, terrorism, banditry and cattle rustling has constrained the Nigerian government to introduce several crime fighting approaches. Despite government efforts, especially through State security forces, crimes have assumed a worsening dimension with increasing cases of attacks and abduction of villagers, worshippers, travellers and other settlers around Nigeria. Schools around the country are not spared, as both students and staff of different levels of educational institutions are kidnapped for ransom and sometimes killed by bandits and terrorists. Many Nigerian farmers have also been forced to abandon their farms due to incessant attacks. Not only are lives and property threatened, the Nigerian economy is also distressed by the impacts of insecurity on agriculture and the attendant hike in the prices of essential food commodities. Following the seeming inability of regular government crime fighting approaches to substantially deal with Nigeria's rising insecurity, this paper examined the application of stakeholder relations perspectives to approach the country's worsening insecurity. The qualitative paper combined Stakeholder and Relational Dialectics as theoretical cornerstone. It examined the impacts of some crime-yielding challenges, such as, illiteracy, unemployment, poverty, economic inequality and pseudo-social participation on the meteoric rise in crime in Nigeria. The paper recommended the application of dialogue in managing the rising militia activities and crimes. It was also recommended that beyond equipping State security formations, Nigerian government should direct attention to the conditions that breed crimes in the country.

KEYWORDS

Crime Explosion; crime-yielding conditions; insecurity; Nigeria's Security Forces; Stakeholder Relations Perspectives.
\end{abstract}

\section{INTRODUCTION}

In every society, crime represents a critical social stakeholder, even though some countries of the developing South do not consider it so. The recognition of crime as a social stakeholder underscores the formation of security machineries, who are saddled with the role of enforcing laws and maintaining order. Crime prevention and management also account for the yearly budgetary appropriations to security and the provision of correctional facilities for hardened criminals whose impenitence may threaten social order. This is a global practice, since crime is not peculiar to developing countries but a global image. 
In Nigeria, for instance, other than regular budgetary appropriations to security, State governors and other levels of political leadership are said to receive monthly security votes, the sum of which derives from the resources accruable to individual governmental authorities. The implication is that crime is a critical social stakeholder that should be conscientiously engaged in order to maintain a crime-free society that enables socioeconomic and political activities to thrive. It also means that investments in managing the causes of crime must be purposefully determined.

The unprecedented rise in crimes in recent years has constrained Nigerian government to introduce several advanced anti-crime and anti-terrorism approaches. For instance, in 2011, the Federal Government of Nigeria criminalised terrorism by passing into law the Anti-Terrorism Act. The Federal Government also enhanced security surveillance by installing computerised close circuit television cameras (CCTV) in strategic locations around the nation and strengthening State security apparatuses through provision of advanced security facilities (Ighomereho and Akpor-Robaro, 2013). As a follow-up, President Mohammadu Buhari, in his inaugural speech in 2015 directed the relocation of defence headquarters to Maiduguri, Borno State. This is in addition to the constitution of several military formations, such as, Operation Crocodile Smile, Operation Python Dance and Operation Lafia Dole to check the rising crimes and militia activities around Nigeria.

Despite these advance security mechanisms, Nigeria, at least, since 2015 has rather witnessed worsening security situations. There have remained ceaseless attacks on villagers, travellers, farmers, worship centres, schools, markets and other public places. Also, not only is the country confronted with terror activities by the Boko Haram insurgents but also with the emergence and devastating activities of bandits, in addition to rise in farmers-herders clashes, kidnapping, cultism, political thuggery, armed robbery and cattle rustling. It is feared that Nigeria and its people may have to face a period of worsening food crisis due to the activities of bandits, herders and terrorists that have forced thousands of farmers away from their farm settlements and displaced several villagers. Several schools in early 2021 alone, especially in Northern Nigeria, were forced to short down due to fear of attacks. Several students of different categories of Nigeria's educational institutions have been kidnapped by bandits and terrorists. Some were killed and families forced into penury on account of sourcing for ransom to free their wards from their abductors. It seemingly appears that Nigeria's insecurity has defied immediate solutions of the deployment of State security apparatuses. This condition is made worse by the fact that members of terror groups, bandits and other social traitors live in the community and are said to win followers taking advantage of the prevailing socioeconomic conditions, such as, illiteracy, poverty and unemployment. The question is: to what extent can the Nigerian government win the war against rising crimes and militia activities with crime-breeding conditions, such as, illiteracy, poverty and massive youth unemployment in place?

\section{Operational Definition of Terms}

The following terms were defined in the manner they were applied in the body of the work and not the lexical meaning.

Crime Explosion: This term defines the rising crimes, such as, kidnapping, armed robbery, cultism, banditry, political thuggery and internet frauds, otherwise referred to as Yahoo in the Nigerian parlance. The term also incorporates insurgency, which has remained a thorn in the flesh of Nigerian people and government since 2009.

Crime Fighting: As noted in the introductory section of this work, the Nigerian government has been constrained to fight crime, especially terrorism and banditry using 
State security forces. Foreign partners have also been incorporated and exploited in the fight against the rising crimes in Nigeria. These efforts cost the government huge human and material sacrifices, as several personnel of different security forces have been lost to the fight against crime in Nigeria.

Crime Management: Crime management is the variant to total use of the force of State security apparatuses to respond to crime. It embraces genuine identification and eradication or, at least, mitigation of the causes of crime. It is devoid of the use of maximum force to deal with issues that rather require humanitarian approaches. Crime management was experimented in Nigeria in 2012, in the Amnesty Deal between the Federal Government and Niger Delta militants.

Stakeholders: These are individuals and groups that are affected by a situation. Stakeholders can also be defined as individuals and groups that may by affected in the execution of a project. In the prosecution of Nigeria's security project, the identification of the interests of stakeholders, such as, the government, State security forces, non-state militia groups, ethnic and regional opinion facilitators, opinion leaders, affected communities and groups and other partners is fundamental to success.

Stakeholder Relations Perspectives: This is the application of public relations approaches in managing a situation, such as, a conflict or crisis. This process embraces the identification and negotiation of the impacts of a situation on affected stakeholders. Stakeholder relations perspectives exploit the power of communication to reach a compromise. It does not neglect or undermine the conditions that underlie a conflict or crisis which must be resolved in order to establish lasting solutions and genuine stakeholder cooperation.

\section{LITERATURE REVIEW}

\section{Theoretical Underpinnings}

This paper was anchored on Stakeholder and Relational Dialectics theories. Other related concepts were reviewed to highlight the focus of the paper.

\section{Stakeholder Theory}

The stakeholder theory was propounded by Edward Freeman in his book "Strategic Management: A stakeholder approach" in 1984 (Heath, 2005). The theory emphasises the establishment of mutual understanding with relevant policy stakeholders through participatory decision-making and other relational approaches. This is based on the argument of Freeman (1984) that the leadership of social or organic communities ought to maintain links with different stakeholders in order to sustain mutual understanding and reduce stakeholder conflicts (Ulmer, Seeger and Sellnow, 2005). The theory contends that social or corporate policy objectives must be pursued with the interests of relevant stakeholders in view.

According to Grunig and Repper (1992), cited in Heath (2005), the importance of the stakeholder approach is based on the fact that the implementation of policy objectives often goes with implications for affected individuals or groups. In order to ensure the cooperation of these groups during decision or policy implementation, it is instructive to involve them in policy-making processes (Heath, 2005; Tench and Yeomans, 2014; Seitel, 2011; Bruning and Ledingham, 2011). The condition that necessitates this interface in decision and policy-making is due to the fact that the leadership of social or organic communities depends on these groups in the realisation of policy objectives. If policy implementation requires the cooperation of relevant stakeholders, it becomes precautionary to involve such stakeholders in policy-making processes. The thesis of the stakeholder 
theory is that social relationship is an ongoing process of accommodation and this accommodation can only be strengthened through stakeholders' participation in strategic policy planning and implementation processes.

\section{Relational Dialectics Theory}

The relational dialectics theory was propounded by Leslie Baxter and Barbara Montgomery in 1996 (Griffin, 2000). The theory is concerned with the complexities and conflicting pulls that characterise social relationships and stakeholders' cooperation due to differences in individuals' or groups' dispositions. What this means is that relationships are built around the changing interplay of opposing forces. These forces represent stakeholders' opposing views about a phenomenon. Proponents of relational dialectics theory draw attention to the tensions, struggles and conflicts that are associated with relationship among interdependent groups. This distressing nature of social relationship accounts for the lamentation of Baxter and Montgomery (1996) that whatever the form of intimacy, social relationship is an indeterminate process of ongoing flux (Miller, 2002).

The implication of the distressing nature of social relationship is that the desire and effort to maintain cordiality among members of a social system presupposes the understanding and anticipation of disagreements over given issues. These disagreements represent what Griffin (2000) describes as contradictions that try social relationship due to the continual interplay of unified oppositions. Since social relationship continually encounter tensions due to contradictions, McGregor (1957), cited in Miller (2006), suggests that the adoption of participatory approaches will help to minimise conflicts in a social system.

The indeterminate nature of social relationship buttresses the inevitability of conflicts among interdependent groups. This accounts for why the relational dialectics theory describes the relationship between members and sections of a social system as a paradox. The paradox lies in the precipitation of contradictions which sometimes separate the interests of these groups. A contradiction manifests whenever the desires or interests of interdependent groups negate one another in principle or approach (Griffin, 2000).

To illustrate the fragility of social relationship, Griffin (2000) conceptualises the relational dialectics theory under the following opposites:

Connectedness and Separatedness: While connectedness exemplifies the sustained effort to establish and maintain mutual understanding between interdependent groups, separatedness represents the futility of establishing a relationship that will be immune to tensions. Griffin (2000) thus argues that no form of relationship can survive except interdependent parties are willing to sacrifice some individual autonomy.

Certainty and Uncertainty: According to Griffin (2000), the articulation of the uncertainty reduction theory by Berger (1987) has identified the importance of ensuring greater flow of information in stakeholder relations. This is targeted at reducing uncertainties or stakeholder conflicts. The relational dialectics theory of Baxter and Montgomery does not contemplate to contradict the importance of communication in building and maintaining stakeholder relations but accentuates the understanding that stakeholder relations does not simply translate into the avoidance conflicts. Griffin (2000) observes that the occurrence of conflicts in a social or work environment represents a spice of variety. He adds that stakeholder conflicts should be functionally exploited to strengthen relationship.

Openness and Closeness: The contradiction in these opposites lies in the paradox that managing stakeholder relations can enhance openness and closeness due to the occurrence of conflicts that pull interdependent parties apart. Stakeholder relations experiences greater 
openness when conflicts are functionally managed and closeness when conflicts are poorly resolved.

Relational dialectics theory proposes that the leadership of a social or organic society should anticipate and develop structures to manage conflicts arising from opposing interests. Griffin (2000), summarising the relational dialectics theory, maintains that dialectical tensions provide opportunities for dialogue. He adds that conflicts provide occasions "when partners could work out ways to mutually embrace their conflicting desires for unity with and differentiation from each other" (p. 165). The condition is that, if the forces that tend to separate sections of the society involve the protection of the interests of each other, joint efforts must be made to reach a consensus. It is the importance of this consensus that underscores participatory approaches in decision-making and conflict management processes.

Stakeholder and Relational Dialectics theories have been criticised for emphasising the complexities and contradictions that are associated with stakeholder relations. The theorists, in defence, suggest clear-cut approaches that can deal with such contradictions. According to Bakhtin (1981), cited in Griffin (2000), dialectical tensions rather than being conceived as contradictions should be seen as opportunities for dialogue - occasions that beckon on individuals and groups to participate in working out ways to mutually embrace their differences and to negotiate their progress.

\section{Defining Policy/Project Stakeholders}

Before examining the groups that constitute policy stakeholders, it is important to establish the understanding of what is meant by a stake. A stake is a right, share or claim an individual or a group has in a project (Heath, 2005; Center, Jackson, Smith and Stanberry, 2008). It is the claim or a right in an undertaking. The right may be a legal claim of ownership or a share in an undertaking. It may also be an ethical claim or interest in the project (Kotler, Maon and Lindgreen, 2012). What this means is that apart from the legal claim of ownership which is often asserted by the government, it is important to identify the interests of other groups that are affected or may be affected in the execution of a project. A stake could be a claim to certain kinds of treatment or benefits. Individuals and groups who make these claims are referred to as stakeholders (Lattinore, Baskin, Heiman and Toth, 2007; Tench and Yeomans; 2014; Nkwocha, 2016).

Policy stakeholders, therefore, are individuals or groups who can assert either legal claims of ownership or other forms of stake in a policy (Kotler, Maon and Lindgreen, 2012). According to Heath (2005), stakeholders can be located within and outside a social or organic system. In the prosecution of Nigeria's security project, identification of the interests of stakeholders, such as, the government, State security forces, non-state militia groups, ethnic and regional opinion facilitators, opinion leaders, affected communities and groups and other partners is crucial to achieving success. The list of project stakeholders has been expanded to include future generations, non-human species (animals) and the natural environment (Heath, 2005; Kotler, Maon and Lindgreen, 2012). The inclusion of future generations, animals and the natural environment in the list of project stakeholders is based on the importance of preserving the earth and its support system. This account for the definition of sustainable development by the World Commission on Environment and Development as development that meets the needs of the present generation of the inhabitants of the earth without compromising the well-being or welfare of future generations (Asadu, 2009).

Wheeler and Sillanpaa (1997), cited in Kotler, Maon and Lindgreen (2012), have categorised project stakeholders into: primary and secondary stakeholder groups; and 
social and non-social stakeholder groups. Primary-social stakeholders are host communities. Secondary-social stakeholders involve groups, such as government, regulatory authorities, civic institutions, pressure agitators, the mass media and academic commentators. In the Nigerian security project, pressure agitators could represent non-state militia groups (such as, bandits and terrorists) and aggrieved ethnic/regional secessionist agitators. On the non-social divide, Wheeler and Sillanpaa (1997) identify primary nonsocial stakeholders as the natural environment, future generations and non-human species (animals). Secondary non-social classification involves environmental interest groups, such as, Friends of the Earth and Greenpeace and animal welfare organisations, such as, People for the Ethical Treatment of Animals (PETA).

The twist with stakeholder relations lies in the urgency with which a non-core stakeholder group, can assume the status of a core stakeholder. This occurs due to the urgency of the claim asserted by a stakeholder on the leadership of a social or organic system. In other words, a secondary non-social stakeholder, such as, a militia group can assume the place of a primary stakeholder due to the urgency it requires to respond to the claim or agitation of the group. Kotler et al (2012) state that a secondary stakeholder group, for instance, can quickly become a primary or core stakeholder when the urgency of a claim takes precedence over the legitimacy of such a claim. What this means is that, it does not matter the legitimacy of a claim asserted by a stakeholder. This is because the urgency of attention it requires to deal with or respond to such a claim can override the legitimacy of the claim on a normal day. The implication of the urgency of a claim that can be asserted by a group is that the leadership of a social or organic system must respond appropriately to the urgency of a claim.

In the Nigerian security and crime situation, the urgency it requires to respond to the devastating effects of both militia and civil agitators on the economy and the people has compelled the government to initiate advanced security measures to respond to the situation. Without prejudice to superiority of the government, the urgency it requires to deal with rising security challenges seemingly requires the application of stakeholder relations approaches, at least, to examine genuine claims and to exploit the security strategies of militia agitators to strengthen overall security intelligence of the nation. Powell (2015) thus observes the incorporation of stakeholder relations approaches in executing an internal security project. This civil-military relations approach enables the assessment of social and economic implications of a security situation on affected groups. It also encourages the incorporation of advanced security trainings into government rehabilitative programmes to enlist repentant agitators into regular State social and security frameworks.

\section{Stakeholder Relations Conflict/Crisis Management Perspectives}

A conflict can be defined as a disagreement between two or more individuals or groups. It is a disagreement or controversy between two or more groups (Singh, 2008). This condition results when there exists an incompatibility or a contradiction that affects the interests of interdependent groups. Griffin and Moorhead (2007) thus define conflict as the resultant situation when there is a conflict of interests of interdependent groups. This condition brings a feeling of discomfort and disharmony between the parties. The interpretation of the foregoing definitions is that conflict is a product of interaction. It also means that conflict is inevitable in a social or organic system. The inevitability of conflicts stems from the fact that humans, within their social or organic environment, must engage in one form of intercourse or the other to accomplish desired goals (Hames, 2012). Many times, the pursuit of some desired benefits engender consequences (positive or negative) 
for other members of the social or organic environment. This is the situation that engenders conflicts. The feeling of inequality and relative deprivation also fuels conflicts in a system (Miller, 2006; Singh, 2008; Regester and Larkin, 2008).

According to Griffin and Moorhead (2007), what becomes a conflict may have lurked around without due attention. They add that, while a conflict situation may emerge as a result a specific event or issue, what becomes a conflict may have been brewing for some time. Pondy (1967), cited in Miller (2006), identifies five stages or phases of conflicts. They are: latent conflict phase, perceived conflict phase, felt conflict phase, manifest conflict phase and conflict aftermath phase.

Conflict is said to be imminent due to the inevitability of conflicting interests among interdependent groups (Griffin and Moorhead, 2007; Singh, 2008). The point is that even when there is no conflict, the complexity of working together to achieve unified or collective gains makes conflict inevitable in a social or organic system. This is the latent conflict phase.

According to Singh (2008), the emergence of incompatibility in the desires of interdependent groups is an indication that a conflict is brewing. At this stage, no conflict has occurred but it is known that a conflict knocks around and that efforts are required to address the situation in order to maintain a united front. At this perceived conflict stage, it is obvious that a conflict is around and requires immediate actions to deal with. Singh (2008) describes this conflict phase as the stage at which people are aware that the existing incompatibility could precipitate a disagreement. For instance, the deprecation of political zoning arrangements, political and institutional appointments in Nigeria were defining conflict indicators that should inform the leadership of the nation that ethnic/regional conflicts were imminent. The state of literacy and heightened unemployment in the country are also sufficient indications of felt conflict. It is rather regrettable that these warning signs are often neglected, trivialised and politicised. This is a negation of the proactive stakeholder relations efforts that should ensure that such agitations do not fester into serious conflicts (Nwosu, 2006; Nwodu, 2007). The result of the continuous leadership indifference to the conflict-yielding conditions is the heightened security and secessionist agitations that currently threaten the nation.

The felt conflict phase is a near conflict stage (Miller, 2006). The response of concerned authorities to manage the situation will make or mar the conflict process. Singh (2008) states that conflicts fester when people try to deny the presence of incompatibility. He adds that rather than denying conditions that can affect social stability, economic growth and development, efforts should be made to effectively use such conditions to strengthen stakeholder relations. This is the opportunity that beckons on Nigeran authorities to urgently rise to crime-breeding conditions, such as, illiteracy, unemployment and poverty and to negotiate through rising secessionist agitations to strengthen the ailing ethnic/regional bonds.

The manifest conflict phase is the stage at which an actual conflict has occurred. Singh (2008) describes this conflict stage as a stage of open conflict. This is the stage Nigeria occupies with worsening security crises and secessionist agitations. The task before the Federal Government at this point is to initiate consultations, especially with groups with genuine agitations and to meaningfully engage conditions that enable crime to flourish.

The conflict aftermath phase is a post-mortem conflict management effort. It involves the evaluation of the strategies that were used in managing a conflict to determine their efficacy or otherwise. It also involves the assessment of the nature of stakeholder relations in the post conflict economy. Conflict aftermath will be crucial in establishing the restoration of genuine cooperation with militia and other violent groups in Nigeria in the 
post security crisis economy. Miller (2006) states that conflicts can produce short-term and long-term consequences for a social or corporate system. Such consequences can be positive or negative and should be determined in order to ensure mutual cooperation and to avoid frequent conflicts.

\section{Conflict Management Perspectives}

Conflict management involves both preventive and curative measures (Singh, 2008). According to (Nwosu, 2006), the preventive conflict management perspective involves attitudinal and proactive measures. It is it is attitudinal when leadership demonstrates willingness to address the conflict situations plaguing the society, including the acceptance of failures and inefficiencies. Conflict management is proactive when leadership ensures the eradication of conflict-breeding conditions.

According to Nwosu (2006), the proactive conflict perspective is the most useful brand of stakeholder relations management. This is because the proactive leadership does not wait for conflicts to occur but creates structures that enable progress in the face of incompatibilities. The importance of the proactive conflict management perspective is that when functionally applied, it can minimise the occurrence of conflicts. It also equips the leadership of a social or organic society with the capacity to adequately respond to eventual emergencies, especially since conflict is inevitable.

The curative conflict management perspective refers to measures that are used to deal with actual conflict situations. According to Singh (2008), the curative conflict perspective becomes relevant when a conflict has occurred and could be detrimental if allowed to fester.

There are two major curative conflict management measures. They are: negotiation and arbitration. According to Griffin and Moorhead (2007), negotiation, otherwise referred to as dialogue or bargaining, involves the process through which two or more parties try to resolve an issue even though they have different views regarding the issue. It involves a formal forum at which disputants make effort to settle their differences (Miller, 2006). What this means is that negotiation involves face-to-face interactions by groups in a conflict and that those interactions are determined by the groups themselves. In other words, negotiation is not a coercive process. Galvin and Terrell (2001) thus define negotiation as "a formal problem-solving process in which people voluntarily discuss their differences, work out a settlement and come to an agreement" (p. 233).

Negotiation appears the way forward out of the growing violent and secessionist agitations Nigeria is currently confronted with. This is because negotiation provides the atmosphere for frank expression of views, including dissensions (Udoudo, 2009). Negotiation will provide opportunities for aggrieved groups whose agitations and sometimes, gorilla approaches put Nigeria at the precipice of disintegration to state their grievances, advance reasons for their views and understand the plight of other groups involved in the conundrum. This perspective could enable the adoption of continuous collaboration in solving the country's many socio-political crises instead of the seeming sole State security perspective.

Sometimes, groups involved in a conflict may fail to resolve their differences through negotiation. This is possible due to sharp incompatibilities and the manifestation of hostilities. When negotiation becomes deadlocked, arbitration becomes the alternative (Galvin and Terrell, 2001). Arbitration, otherwise referred to as mediation, involves the engagement of an objective and neutral party (often called the mediator, third party or gobetween) to help others to resolve their differences (Galvin and Terrell, 2001). The 
mediator or mediating team must be known and approved by groups involved in a conflict. This is to ensure parties' confidence in the process.

Arbitration is an alternative to negotiation or any other process initiated to manage a conflict between parties. According to Miller (2006), arbitration or the third-party conflict management perspective comes handy when groups involved in a conflict fail to resolve their differences through other means of conflict resolution. Arbitration is essentially initiated to prevent a conflict from festering into a major crisis (Galvin and Terrell, 2001). In view of the impacts of the present security challenges on households, businesses and the Nigerian economy, it may not be out of place to experiment genuine arbitration. The problems of banditry, terrorism and secessionist agitations can be discussed. This is not only to raise the confidence of aggrieved parties in the process but also to provide lasting solutions to the rising tempestuous agitations.

\section{RESULTS AND DISCUSSION}

\section{Managing Nigeria's Crime-Yielding Images}

Nigeria is bedeviled by several crime-yielding conditions. The continuous presence of these conditions has made a mockery of different crime-fighting tactics of successive administrations. Some crime-yielding images in Nigeria were examined under the following headings:

\section{Illiteracy and Low-Sense of Power}

Illiteracy is the state of not knowing how to read or write. The illiterate is intellectually blind, deaf and dumb. He is intellectually handicapped and his intellectual incapacitation makes him vulnerable and gullible. His gullibility makes him a burden to the society. This is because he can easily be exploited to work against his personal and public interests. Reddi (2009) describes the illiterate as a liability to the society. To this extent, rather being a builder of the nation, the illiterate constitutes some potential agents of retrogression.

The rate of illiteracy in Nigeria is massive despite supposed government investments in promoting basic education. According to Nigeria's Minister of Education, Mallam Adamu Adamu, about sixty-six percent of Nigerian children, especially those in rural areas, cannot read and write (Punch Editorial, 2020). Earlier in September, 2017 at a courtesy call on Governor of Kebbi State, Alhaji Atiku Bagudu, Mallam Adamu admitted that Nigeria's illiteracy burden is alarming. The Minister disclosed that about sixty-five to seventy-five million Nigerians were illiterates (News Agency of Nigeria, 2017; Idoko, 2017). In 2019, the Federal government's survey of the growth of literacy indicated that there were over ten million out of school children, aside from illiterate adults (Erunke, 2020).

Several socio-political and economic challenges Nigeria is confronted with cannot be divorced from illiteracy. This accounts for why the National Commission for Mass Literacy, Adult and Non-Formal Education (1990), cited in Bakare (2011), observes that there is a connection between illiteracy, poverty and crime in Nigeria. The Commission states that high rate of poverty in Nigeria has its root in illiteracy. What this means is that any effort directed at addressing poverty and crimes in Nigeria must embrace the promotion of literacy. Dauda (2010) shares this view as he argues that educational development is the foundation of sustainable development. He avers that any effort that is directed to enhance sustainable economic growth and development must embrace aggressive eradication of illiteracy. 
Not only does illiteracy leave citizens incapacitated to participate in social development processes, it also leaves them perpetually incapacitated to hold the government accountable to its responsibilities. Adeyemi, Ijaiye and Kolawole (2006), cited in Nwanmereni (2021), argues that any development effort that does not raise the capacity of citizens to articulate their development priorities is an unimpressive development paradigm. Citizens' intellectual incapacitation which has its roots in illiteracy and manifests in low sense of power is the foundation of clientele politics in Nigeria. Illiteracy is the foundation of poverty in Nigeria. It is largely responsible for substance abuse, political thuggery, ballot trading, prostitution and several criminal activities that threaten social stability in Nigeria. It is only precautionary to consciously tackle the conditions that make the illiterate susceptible to crimes rather than waging an endless war against potential wealth of the nation. It is also precautionary to aggressively address massive structural and infrastructural decays in Nigeria's educational sector in order to produce graduates who have the capacity to contribute to national growth and development.

\section{Managing Nigeria's Unemployment and Poverty Factor}

Unemployment is the situation whereby people who have requisite skills and are willing to work are unable to find jobs due to scarcity of employment opportunities in a society. It is the situation where the labour market is unable to provide jobs for a country's labour population (Udu and Agu, 2005; Jhingan, 2006; Obutte, 2012). This structural unemployment situation does not recognise the possession of skills, since such skills do not guarantee job placement for the holder. This is the situation Nigeria occupies, where the country's teeming labour population lack employment opportunities despite the possession of skills and certificates.

Nigeria is also confronted with the problem of under-employment. This is a near unemployment situation where someone's job cannot solve the basic needs of food, shelter and clothing in a sustainable manner. Harold (2009), cited in Kayode, Arome and Anyio (2014) defines under-employment as the situation where people are engaged in unproductive jobs, with low wages that are insufficient to meet their basic needs. Many Nigerians who are employed earn less than one dollar a day. This is against the international threshold poverty line of 1.90 dollars per day (World Bank, 2020).

Unemployment cannot be extricated from poverty. This is because someone who is unemployed is poor and cannot meet his basic needs. When people are unable to meet their basic needs, especially the need to overcome hunger, they constitute threats to the society. The International Labour Organisation (2012) observes that unemployment is one of the biggest threats to social stability around the world.

It is unarguable that unemployment and poverty are the twin roots of several crimes that currently threaten social order in Nigeria. Crimes, such as, kidnapping, prostitution, ballot trading and several other criminal activities have roots in unemployment and poverty. Hassn (2010), cited in Kayode et al (2014), shares this view as he avers that kidnapping, civil unrests and political thuggery in Nigeria can be traced to the unemployment situation in the country. This is true since the idle mind can easily be engaged by the minutest supposed promising transactions, even when such transactions are criminal. In view of the attendant consequences of unemployment and poverty, it is only precautionary to urgently deal with conditions that drive unemployment in Nigeria, such as mono-economic structure, bad governance, corruption, and institutional and infrastructural decays rather than equipping security forces to neutralise the consequences of unemployment and poverty. 


\section{Inequality (Rich-Poor Gap) Factor}

Inequality refers to the situation where some people have greater access to opportunities than others. It can also be defined as lack of evenness in the distribution of political and economic opportunities. The foregoing definitions demonstrate that inequality involves some level of denial or deprivation which leaves the marginalised at a disadvantaged position. It shows that inequality can prevent the deprived from maximally exploiting social, economic and political opportunities and cannot compete favourably with his contemporaries. Akpoilih and Farayibi (2012) observe that poverty in Nigeria is partly a function of unequal distribution of income, social infrastructure, education, skills and other socio-political and economic opportunities.

Unequal distribution of economic opportunities could be systemic or ruminative. It is systemic when inequality results from institutional failure in the provision of equal opportunities for citizens (Akpoilih and Farayibi, 2012). It is ruminative when inequality thrives through the perpetuation tribalism and nepotism in defiance of the value of merit and hard work. Akpoilih and Farayibi (2012) argue that inequality in Nigeria results from endemic corruption in the system.

According to Aigbohkan (2000) and World Development Report (2000), cited in Odozi (2012), there is a connection between inequality, poverty and insecurity in Nigeria. This is because the gap between the poor and the rich, especially the political class, fuels the feeling of deprivation. It is the feeling of deprivation that creates the conditions for catalogue of social problems. Odozi (2012) suggests that problems associated with inequality can be mitigated by initiating actions that eliminate discrimination and giving priority to the poor who lack most relative social opportunities. It is only when such actions are conscientiously implemented that the problems associated with the feeling of relative deprivation and being pauperised by the political class could be mitigated.

\section{Pseudo-Social Participation Factor}

Participation refers to the involvement of concerned stakeholders in planning and executing a project (Forrester, Swartling and Lonsdale, 2008). It also means seeking the collaboration and cooperation of relevant stakeholders in policy-making and implementation (Deverka, Lavellee, Desai, Esmail, Ramsey, Veenstra and Tunis, 2012). Ratnam (2006) shares this view as he identifies the goals of participation as: Communication - to give and get information; Consultation - to obtain other people's views; Participation - to let the people concerned take part in a project; and Joint Decision-making - incorporating the views of concerned stakeholders in a decision (p. 534).

The goal of engaging concerned stakeholders in project planning and execution presupposes the understanding of the importance of eliciting stakeholders' views in solving a problem. Pugh and Hinson (1989), cited in Miller (2006), observe that dependable group decisions are made through genuine consultation and collection of stakeholders' views on a project. By describing participation as a process that thrives through consultation, collection and collation of stakeholders' views, it means that participation should provide the atmosphere that encourages frank expression of views, including dissensions.

White (1994), cited in Nwanmereni, Ochonogor and Orlu-Orlu (2020), makes a distinction between pseudo-participation and genuine participation. According to White (1994), pseudo-participation simply means decision imposition. A practical example of pseudo-participation in the Nigerian situation takes effect when citizens' ignorance and low sense of power is exploited by the government to actualise some predetermined gains, many times to the disadvantage of the people. This is what happens when a political representative, for instance, is selected for a senatorial district by political leadership 
without input by constituents. White (1994) sub-categorises pseudo-participation into domestication (which involves informing, therapy and manipulation) and assistencialism (which involves false benevolennce). What this categorisation means is that pseudoparticipation is manipulative.

Pseudo-participation has remained a breeding ground for violent agitations in Nigeria. Rising secessionist agitations around the nation are hinged on the feeling of economic and political deprivations driven through pseudo participatory political offerings. The claims and counter-claims of the subjugation of Federal Character in institutional appointments and the deprecation of political benefits in the present administration are manifestations of the feeling of relative deprivation. Many times, these seeming deprivations are perpetuated through pseudo participatory approaches that do not encourage utilitarianism. These are the conditions that have continuously promoted hatred, provoking the aggrieved and oppressed to constantly seek opportunities to settle some scores with the regime in power. To eradicate or mitigate ethnic and regional conflicts that have political colourations, the Nigerian political class must encourage genuine citizen participation in political and social processes.

\section{CONCLUSION}

It is doubtless that crime is a global image, since nations of the world have their population of people who seemingly do not share the willingness to engage in productive vocations. What is unarguable, however, is that the meteoric rise in crimes, such as, kidnapping, political thuggery, banditry and terrorism in Nigeria have roots in some socio-economic challenges plaguing the nation, especially illiteracy, unemployment and poverty. Obviously, government's effort at eradicating these crimes through State security forces have yielded rather abysmal results. This is the condition that necessitates the incorporation of stakeholder relations perspectives to engage crime-yielding structures in Nigeria. This is precautionary since the efforts that are directed at eradicating crimes must embrace the eradication of underlying crime-yielding conditions to be successful.

\section{Recommendations}

Based on the distressing escalation of crimes in Nigeria despite advanced State security measures, the following recommendations were suggested:

1. Beyond equipping State security forces, the Nigerian authorities should direct attention to conditions that enable crimes to flourish. If the reported huge allocations that Nigerian governors collect as security votes are directed to tackling unemployment, poverty, illiteracy and inequality, crimes will substantially reduce to the state that can be successfully prosecuted with regular budgetary appropriations to security.

2. In view of the rising crimes despite the introduction of advanced security measures, it is precautionary to incorporate some level of dialogue to approach the lost sheep. The impacts of illiteracy, poverty and substance abuse on crimes, such as, cultism, banditry and political thuggery cannot be overlooked.

3. Urgent and conscientious efforts are required to defeat illiteracy. This is because the illiterate is vulnerable, gullible and constitutes a threat to social stability. It is difficult to divorce the susceptibility of some Nigerian young people to embrace crimes and violent activities from illiteracy.

4. It is not enough to acknowledge that the idle mind is the devil's abode, conscientious efforts are urgently required to reduce unemployment in Nigeria. This is because the unemployed youth who is poor and cannot afford his basic needs could easily enlist into any seemingly promising criminal activities to survive. 
5. It is also important that the current political administration encourage genuine negotiations and social inclusion to eradicate the feeling of deprivation. The current secessionist agitations can be productively exploited through genuine consultations and negotiations to build a united Nigeria. The willingness to admit obvious deprivations and to make compensatory offerings, where necessary, could ultimately douse the growing secessionist agitations and violent conflicts currently threatening Nigeria's unity.

\section{REFERENCES}

Akpoilih, R. \& Farayibi, A. (2012). Economic growth and inequality in Nigeria: Magnitudes and Challenges. Retrieved from https://mpra.ub.uni-muenchen.dc/74156/ on July 16, 2021.

Asadu, C. A. (2009). Anatomy of communication for development, Port Harcourt: University of Port Harcourt Press.

Bakare, A. S. (2011). A critical appraisal of the linkage between literacy rate and the incidence of poverty in Nigeria: Journal of Emerging Trends in Educational Research and Policy Studies, 2 (6), 450-456.

Bruning, S. D. \& Ledingham, J. A. (2000). Organisation and key public relationships: Testing the influence of the relationship dimensions in a business-to-business context. In S. D. Bruning \& J. A. Ledingham (Eds). Public relations as relationship management: A relational approach to the study and practice of public relations (pp. 159-173). New Jersey: Lawrence Erlbaum Associate Inc. Publishers.

Center, A., Jackson, P., Smith, S. \& Stansberry, F. R. (2008). Public relations practices: Managerial case studies and problems ( $7^{\text {th }}$ ed). New Jersey: Pearson Education Inc.

Dauda, R. O. S. (2011). Investment in education and economic growth in Nigeria: An empirical Evidence. International Research Journal of Finance and Economic Issues, $55,158-169$.

Deverka, P. A., Lavallee, D. C., Desai, P. J., Esmail, L. C., Ramsey, S. D., Veenstra, D. L. \& Tunis, S. R. (2012). Stakeholder participation in comparative effectiveness research: Defining a framework for effective engagement. Journal of Comparative Effectiveness, $1(2), 181-194$.

Erunke, J. (2020, September 17). Out of school children drops from 10m to $6 \mathrm{~m}$ in $2020-$ FG. Retrieved from www.vanguardngr.com on July 28, 2021.

Forrester, A., Swartling, G. A. \& Lonsdale, K. (2008). Stakeholder engagement and the work of SEI: An empirical study. Retrieved from www.international.org on March 5, 2018 .

Galvin, K. M. \& Terrell, J. (2001). Communication work: Communication applications in the workplace. Illinois: Contemporary Publishing Group Inc.

Griffin, E. M. (2000). A first look at communication theory $\left(4^{\text {th }}\right.$ ed). New York: McGraw Hill Inc.

Griffin, R. W. \& Moorhead, G. (2007). Organisational behaviour: Managing people and organisations $\left(8^{\text {th }} \mathrm{ed}\right)$. New York: Houghton Mifflin Company.

Hames, D. S. (2012). Negotiation: Closing deals, settling disputes and making team decisions. California: Sage Publications Inc.

Heath, R. (2005). Encyclopaedia of public relations. London: Sage Publications.

Ighomereho, I. C. A. \& Akpor-Robaro, M. O. M. (2013). Security challenges in Nigeria and the implications for business and sustainable development. Journal of Economics and Sustainable Development, 4 (2), 79-99. 
International Labour Organisation (2012). Global unemployment trends for youth 2012. Retrieved from http://www.ilo.org/wcmsP5/groups/public/...dgreports/--dcomm/documents/ publication /wcms-180976 on July 28, 2021.

Jhingan, M. L. (2006). Economics of development planning (41 ${ }^{\text {st }}$ ed). New Delhi: Vrinda Publication (PVT) Ltd.

Idoko, C. (2017, November 30). Illiteracy rate in Nigeria still alarming - FG. Retrieved from tribuneonline.com>Education on July 28, 2021.

Kayode, A., Arome, S. \& Anyio, S. F. (2014). The rising rate of unemployment in Nigeria: The socio-economic and political implications. Global Business and Economics Research Journal, 3 (1), 68-89.

Kotler, P., Maon, F. \& Lindgreen, A. (2012). A stakeholder approach to corporate social responsibility: Pressures, conflicts and reconciliation. London: Routledge.

Lattimore, D., Baskin, O., Heiman, S. T. \& Toth, E. L. (2007). Public relations: The profession and the practice ( $\left.2^{\text {nd }} \mathrm{ed}\right)$. New York: McGraw Hill Companies Inc.

Miller, K. (2002). Communication theories: Perspectives, processes and contexts. New York: McGraw Hill Inc.

Miller, K. (2006). Organisational communication: Approaches and processes $\left(4^{\text {th }} \mathrm{ed}\right)$. Belmont: Thompson Wadsworth.

News Agency of Nigeria (2020, September 22). Illiteracy rate in Nigeria alarming, says FG. Retrieved from m.guardian.ng>news on July 28, 2021.

Nwanmereni, D., Ochonogor, C. I. \& Orlu-Orlu, H. C. (2018). Stakeholders' participation in decision-making and conflict management in select tertiary institutions in Rivers State. International Journal of Education and Evaluation, 4 (5), 91-100.

Nwanmereni, D. (2021). Investigating the communication components of Nigeria's post covid-19 economic recovery policy. Journal of Development Communication, 32 (1), 21-32.

Nkwocha, J. (2016). Reputation management and branding: With Nigerian case studies. Port Harcourt: Biz Publishing \& Printing Company Limited.

Nwodu, L. C. (2007). Corporate public relations management. Enugu: Precision Publishers Limited.

Nwosu, I. E. (2006). Public relations as a veritable tool of industrial relations management: A critical and prescriptive analysis. Journal of Nigerian Institute of Public Relations 3 (1), 40-53.

Obutte, P. C. (2012). Multilateralism and sustainable development: Perceptive on international practice, polices and legal instrument. In L. Popoola, O. Olaniyan \& O. Olayide (Eds). Building resilience in sustainable development in the changing world (pp. 22-48). Ibadan: Centre for Sustainable Development.

Odozi, J. C. (2012). Socio-economic gender inequality in Nigeria: A review of theory and measurement. Retrieved from https://mpra.ub.uni.muenchen.de/41826/ on July 28, 2021.

Powell, J. (2015). Terrorists at the table. New York: St. Martins Press.

Punch Editorial (2020, December 10). Reversing the rising illiteracy among Nigerian children. Retrieved from www.punchng.com on July 28, 2021.

Ratnam, C. S. V. (2006). Industrial relations. Oxford: Oxford University Press.

Reddi, C. V. N. (2009). Effective public relations and media strategy. New Delhi: PHI Learning Private Ltd.

Regester, M. \& Larkin, J. (2008). Risk issues and crisis management: A casebook of best practice $\left(4^{\text {nd }}\right.$ ed). London: Kogan Page Publishers. 
Seitel, F. P. (2011). The practice of public relations $\left(11^{\text {th }}\right.$ ed). New Jersey: Pearson Education Inc.

Singh, R. D. (2008). Managing conflict and negotiation. New Delhi: Excel Books.

Udu, E. \& Agu, G. A. (2015). New system economics. Onitsha: Africana First Publishers Ltd.

Udoudo, A. (2009). Managing conflicts in the Niger Delta through functional dialogue. In D. Wilson (Ed). Communication approaches to peace building in Nigeria (pp. 165-179). Uyo: African Council for Communication Education.

Ulmer, R. R., Seeger, M. W. \& Sellnow, T. L. (2005). Stakeholder theory. In R. Heath (Ed). Encyclopaedia of public relations (pp. 808-811). London: Sage Publications.

World Bank (2020). Measuring poverty. Retrieved from www.worldbank.org on July 28, 2021. 